\title{
Persimpangan Dilema Penanganan Pengungsi Asing Di Indonesia Pasca Penerbitan Perpres No. 125 Tahun 2016
}

\author{
Agung Priambodo ${ }^{1}$ \\ ${ }^{1}$ Magister Ilmu Hubungan Internasional, FISIP, Universitas Indonesia \\ agung.priambodo0@gmail.com
}

\begin{abstract}
Cara Sitasi: Agung P (2021) Persimpangan Dilema Penanganan Pengungsi Asing Di Indonesia Pasca Penerbitan Perpres No. 125 Tahun 2016, 2021 21(2), 122-129 Retrieved from https://doi.org/10.31294/jc.v19i2
\end{abstract}

\begin{abstract}
This article aims to unravel the issues of the threat of waves of refugees and asylum seekers in Indonesia. The concept of non-traditional security is adopted in this study as a framework for analyzing social problems of refugees and asylum seekers that have an impact on national security and interests. This research uses descriptive-qualitative analysis method to draw a common thread of threats that may arise along with the implementation of Presidential Decree no. 125 of 2016 concerning Handling of Refugees from Overseas. Referring to the results of data analysis, this study draws four reasons for the possible consequences of the wave of refugees in Indonesia, including: the regulations in Presidential Decree no. 125 of 2016 with other laws and regulations, the dilemma of unlimited stay permits, and the lack of budget allocations for sustainable handling of refugees.
\end{abstract}

Keywords: refugee, non-traditional security, threats, border

\section{PENDAHULUAN}

Isu migrasi, konflik dan pengungsi paksa kini menjadi tiga kata kunci penting dalam wacana isu kemanusiaan dan keamanan global. Berkaca dari dinamika konflik bersenjata di kawasan Afrika, Timur Tengah dan Afghanistan yang berlangsung dalam kurun waktu 20 tahun terakhir, tren gelombang pergerakan migrasi kini selalu menjadi isu hangat di berbagai negara khususnya di kawasan Asian Tenggara dan Pasifik. Sebagai negara yang menghubungkan kawasan Australia, Indonesia telah menghadapi isu migrasi pengungsi dan pencari suaka sejak tahun 1975. Peristiwa konflik Vietnam yang terjadi pada tahun 1970 mengakibatkan gelombang pengungsi "IndoCina" masuk wilayah Indonesia melalui laut china selatan (Pugh, 2004). Catatan sejarah memperkirakan pergerakan migrasi penduduk Indo-China pertama kali dimulai pada tanggal 19 Mei 1975 dimana ditemukan sebanyak 92 pengungsi Indo-China singgah di daerah Tarempa, Kecamatan Siantar. Berselang enam hari berikutnya, gelombang migrasi penduduk IndoChina terus memasuki wilayah kepulauan Natuna dan berlanjut dengan gelombang-gelombang 'manusia perahu' lainnya dengan daya angkut yang lebih banyak hingga 1000 orang dalam satu kali kedatangan (Fandik, 2013). Seiring dengan membludaknya kedatangan pengungsi IndoChina, hingga akhir tahun 1979, Pemerintah Indonesia memutuskan membuka area pulau Galang untuk menampung sekitar 25.000 pengungsi sebagai tempat tinggal sementara sebelum adanya kepastian penempatan di negara ketiga.

Pasca peristiwa 'Manusia Perahu' yang berakhir pada tahun 1990an, tren pergerakan Pengungsi dan Pencari Suaka yang berasal dari kawasan Timur Tengah dan Afrika mulai masuk ke wilayah Indonesia pada awal tahun 2000an. Laporan USCRI tahun 2001 menyebutkan bahwa terdapat 373 pengungsi dan pencari suaka yang terdampar di Indonesia dimana keseluruhan pengungsi dan pencari suaka berasal dari Irak, Afghanistan, Iran, Somalia, Liberia, Sierra Leone, dan Aljazair (US Committee for Refugees and Immigrants, 2001). Kendati pergerakan kedatangan Pengungsi dan Pencari Suaka di Indonesia terus mengalami fluktuasi selama 10 tahun terakhir, setidaknya hingga Maret 2021, data UNHCR Indonesia 
menunjukkan sebanyak 13,497 populasi Pengungsi dan Pencari Suaka tersebar di sebelas provinsi di Indonesia. Dominasi populasi Pengungsi dan Pencari Suaka di Indonesia pada umumnya berasal dari negara-negara rawan konflik seperti Afganistan dengan total 7.583 orang, Somalia sebanyak 1,389 orang, Iraq sebanyak 718 orang, pengungsi etnik Rohingya sebanyak 674 orang dan populasi negara lainnya sebanyak 1.357 orang (UNHCR Indonesia, 2021). Kendati Indonesia bukan merupakan bagian dari komunitas negara-negara yang meratifikasi konvensi Pengungsi tahun 1951 dan Protokol tahun 1967, meningkatnya jumlah populasi pengungsi dan pencari suaka di Indonesia tentu tidak terlepas dari dua faktor utama. Pertama, posisi geopolitik Indonesia yang berbatasan langsung dengan Australia sebagai negara yang meratifikasi Konvensi Jeneva tahun 1951 dan Protokol tahun 1967, serta faktor prinsip nonrefoulment yang dianut Indonesia berdasarkan kepada kovenan dan konvensi internasional tentang Hak Asasi Manusia dan Hak Sipil yang telah diratifikasi Pemerintah melalui Undangundang RI Nomor 5 tahun 1998, Undang-undang RI Nomor 39 tahun 1999, dan Undang-undang RI Nomor 12 tahun 2005 (Yulianto, 2020). Kedua faktor inilah yang kemudian menjadikan Indonesia sebagai salah satu negara transit utama kelompok pengungsi dan pencari suaka sebelum mencapai kawasan teritori Australia, meskipun pada akhirnya keinginan dan usaha untuk memperoleh determinan status kewarganegaraan dari Australia terancam sia-sia.

Harapan memperoleh status kewarganegaraan dari Australia bukanlah ancaman semu. Hubungan bilateral Indonesia dan Australia dalam penanganan pengungsi dan pencari suaka di Indonesia berada dalam kondisi pasang surut. Pada tahun 2001, Perdana Menteri John Howard menerapkan kebijakan luar negeri penanganan pengungsi dan pencari suaka melalui penerbitan The Pacific Solution dan melakukan amandemen Migration Legislation Amandement Act No. 6. 2001. Hard policy yang diterapkan oleh Perdana Menteri John Horward kemudian dilanjutkan kembali pada era kepemimpinan Perdana Menteri Kevin Rudd yang menerapkan kebijakan Offshore Processing Center dan Perdana Menteri Tony Abbott (2013-2015) dengan kebijakan temporary protection visa, operation sovereign border, turn back boat policy, offshore processing and settlement, temporary protection dan kebijakan fast-track processing of asylum claims (Lumentut, Pelamonia \& Korwa, 2020). Pada tahun 2018 hingga saat ini, Perdana Menteri Scott Marison masih melanjutkan kebijakan sebelumnya yang tetap melarang imigran ilegal untuk masuk ke wilayah teriori Austalia dan mengembalikannya ke wilayah perbatasan seperti Indonesia atau Papua Nugini (Maing \& Kukab, 2020).

Apa dampaknya bagi Indonesia? Kebijakan imigrasi Australia khususnya yang berkaitan dengan Pengungsi dan Pencari Suaka memunculkan isu keamanan yang signifikan terhadap posisi Indonesia yang berbatasan langsung dengan wilayah Australia. Proses penyelundupan pengungsi ke wilayah Australia dari Indonesia, pada umumnya, dilakukan oleh mafia-mafia jaringan penyelundupan dan human traficking yang dibayar untuk meloloskan perjalanan tersebut melalui jalur laut. Namun, kebanyakan perjalanan ilegal tersebut terhalang oleh Angkatan Laut Australia sehingga kapalkapal tersebut diarahkan kembali ke Indonesia atau diangkut ke titik-titik detensi di Papua Nugini dan Nauru. Kondisi ini diperparah dengan adanya kebijakan pemberhentian suntikan dana Australia untuk IOM (International Organization for Migration) pada tahun 2018 yang memiliki fungsi dan tugas utama untuk menahan laju migrasi pengungsi dan pencari suaka di Indonesia melalui program-program insentif dan pemberdayaan sosial.

Realitas ini memunculkan ancaman yang nyata bagi stabilitas dan keamanan di Indonesia sendiri. Menurut perspektif non-traditional security threat, isu Pengungsi dan Pencari Suaka merupakan salah satu bentuk ancaman terhadap stabilitas keamanan negara yang tidak dapat diselesaikan melalui tindakan-tindakan yang bersifat konvensional atau berbasis militer (Caballero-Anthony, 2016). Menurut Caballero, penyelesaian isu-isu berbasis human security memerlukan keterlibatan antar aktor negara dimana kerjasama dan kolaborasi yang bersifat multilateral menjadi kunci penting dalam rangka melakukan eliminasi terhadap ancaman-ancaman yang timbul. Namun kenyataannya, sikap Australia yang cenderung resisten terhadap kebijakan imigrasinya pada akhirnya menempatkan Indonesia pada kondisi dilematis dan sulit.

Berkaca pada realitas tersebut, penelitian ini bertujuan untuk mengurai kebijakan-kebijakan domestik yang diadopsi pemerintah sebagai respon kebijakan luar negeri Australia dan hukum internasional, khususnya kebijakan pemerintah, dalam menghadapi dinamika penanganan pengungsi dan pencari suaka yang tertahan di Indonesia selama bertahun-tahun. Pendekatan non-traditional security threats diadopsi dalam penelitian ini untuk mengeksplorasi ancamanancaman yang berpeluang muncul sebagai konsekuensi kebijakan domestik yang diambil 
pemerintah dalam hal penanganan pengungsi asing yang tersebar di berbagai provinsi di Indonesia. Analisis penelitian ini secara sistematis dibahas ke dalam lima sub-bagian diskusi antara lain: latar belakang, studi literatur penelitian, metode penelitian, hasil dan pembahasan, dan penarikan kesimpulan.

\section{TINJAUAN PUSTAKA}

Pasca berakhirnya perang dingin, the Copenhagen School merilis istilah 'new security' yang mengeksplorasi bentuk-bentuk ancaman baru terhadap keamanan manusia. Sebagai pencetus pandangan 'new security', aliran Copenhagen menyiratkan karakterisitik keamanan manusia yang mencakup keamanan militer, politik, ekonomi, jaminan sosial dan keamanan lingkungan (Buzzan,et all., 1998). Inisiasi konsep 'new security' mahzab Copenhagen yang komprehensif dan berbasis keamanan manusia mendorong berbagai perspektif baru yang mampu menjawab persoalan-persoalan hubungan antar negara yang dinamis (Caballero-Anthony, 2016). Pandangan inilah yang kemudian memberikan ruang diskusi yang dinamis hingga memunculkan dualisme bentuk keamanan internasional yaitu traditional security dan non-traditional security.

Traditional security merujuk pada fenomenafenomena membahas tentang perang antarnegara berdaulat, perlombaan senjata militer, aliansi keamanan regional, sampai pada perimbangan kekuatan antara negara-negara utama dalam politik internasional (Sudiar, 2019). CaballeroAnthony mendefinisikan non-traditional security sebagai tantangan terhadap kelangsungan hidup dan kesejahteraan masyarakat dan negara yang muncul terutama dari sumber nonmiliter, seperti perubahan iklim, degradasi lingkungan lintas batas dan menipisnya sumber daya, penyakit menular, bencana alam, migrasi tidak teratur, kekurangan pangan, penyelundupan manusia, perdagangan narkoba, dan bentuk kejahatan transnasional lainnya. Menurut Mlynarska, non-traditional security merupakan dasar asumsi dalam menjawab masalah maupun mengidentifikasi isu-isu global dan keamanan manusia seperti ketahanan pangan, keamanan lingkungan, keamanan negara, migrasi paksa, dan krisis kemanusiaan (Mlynarska, 2016). Karakterisitik non-traditional security, menurut Caballero, mencakup pandangan-pandangan berikut: (Caballero-Anthony, 2016):

a. Ancaman tersebut bersifat transnasional terkait dengan asal usul, konsepsi, dan efeknya;

b. Konsep ini bukan dipicu dari persaingan antar negara atau pergeseran keseimbangan kekuasaan, tetapi sering didefinisikan ke dalam wilayah politik dan sosial ekonomi;

c. Masalah keamanan non-tradisional seperti kelangkaan sumber daya dan gelombang migrasi paksa menyebabkan ketidakstabilan sosial dan politik dan karenanya memicu ancaman keamanan;

d. Ancaman lain seperti perubahan iklim sering disebabkan oleh gangguan yang diakibatkan oleh manusia terhadap keseimbangan alam yang rapuh dengan konsekuensi yang mengerikan bagi negara dan masyarakat yang seringkali sulit untuk diperbaiki;

e. Yang dimaksud dengan keamanan bukan lagi hanya negara (kedaulatan negara atau keutuhan wilayah), tetapi juga rakyat (kelangsungan hidup, kesejahteraan, martabat) baik pada tingkat individu maupun masyarakat; dan

f. Solusi nasional seringkali tidak memadai sehingga pada dasarnya membutuhkan kerjasama regional dan multilateral.

Isu pengungsi dan 'human security' dalam perspektif non-traditional security menjadi salah satu topik yang relevan dalam mengurai berbagai ancaman non-militer di kawasan Asia Tenggara. Setidaknya pada konteks masalah pengungsi dan pencari suaka di ASEAN, Bussabong dan Haque (2020) telah mengangkat kasus non-traditional security mobilisasi Pengungsi Rohingya di perbatasan Thailand. Secara berturut-turut sejak tahun 2012, kekerasan yang dilakukan militer Myanmar terhadap etnik Rohingya memicu gelombang migrasi ke wilayah perbatasan Myanmar-Thailand Selatan. Untuk mengidentifikasi non-traditional security threat yang ditimbulkan akibat migrasi etnis Rohingya ke wilayah Thailand Selatan, Bussabong dan Haque melakukan penelitian lapangan untuk memperoleh data analisis yang diperlukan. Hasilnya, keberadaan pengungsi Rohingya, menurut perpektif otoritas Thailand, termasuk ke dalam kategori pekerja illegal dan target korban kejahatan perdagangan manusia. Selain itu kajian ini juga memunculkan tren pernikahan campuran dengan penduduk lokal yang pada akhirnya memberikan kesempatan bagi kelompok etnik rohingya untuk mendapatkan mata pencaharian.

Di Indonesia sendiri, wacana non-traditional security terhadap eksistensi pengungsi dan pencari suaka juga menjadi perhatian Prahenti (2013). Penelitian ini dilatarbelakangi adanya korelasi antara peningkatan jumlah pencari suaka yang transit di Indonesia pada tahun 2009-2012 dengan eskalasi tren kejahatan transnasional di beberapa wilayah provinsi yang cenderung meningkat. Penelitian ini mengajukan hipotesa yang 
membuktikan bagaimana keberadaan pengungsi di Indonesia hanya memberikan dampak sosial yang buruk serta memicu adanya ancaman keamanan non-tradisional. Kendati Indonesia telah memiliki payung hukum UU No. 6 tahun 2011 tentang keimigrasian, pada kenyataannya pengawasan dan pengendalian laju migrasi pengungsi dan pencari suaka belum sampai pada titik yang optimal. Hal ini dibuktikan melalui temuan kasus-kasus kejahatan dimana tren ancaman keamanan berfokus pada permasalahan yang dapat mengancam stabilitas keamanan negara seperti peredaran narkoba, perdagangan manusia, penyelundupan manusia, dan terorisme. Hal ini juga semakin diperparah dengan lemahnya penanganan dan pengawasan mobilisasi pengungsi dan pencari suaka di Indonesia serta kebijakan hard policy imigrasi Australia yang menutup akses masuk gelombang pengungsi ilegal dan pencari suaka yang akan berlayar menuju wilayah teritori Australia.

Mengacu pada kajian Bussabong \& Haque (2020) dan Prahenti (2013), penelitian ini menempatkan posisi yang berbeda dimana analisa yang dilakukan berfokus pada lemahnya posisi Indonesia dalam mengimplementasikan aturanaturan penanganan Pengungsi dan Pencari Suaka yang berpeluang menjadi ancaman stabilitas keamanan negara. Selain itu, prinsip nonrefoulment yang dianut Indonesia hanya memunculkan bom waktu seiring dengan hard policy luar negeri Australia terkait penolakan arus gelombang Pengungsi dan Pencari Suaka melalui berbagai inisiasi kebijakan domestik dan luar negeri.

\section{METODOLOGI PENELITIAN}

Penelitian ini akan menggunakan metode penelitian kualitatif. Metode penelitian kualitatif menitikberatkan pada detail-detail pembahasan dan penjabaran atas fenomena tertentu dalam sebuah rangkaian peristiwa yang diteliti dalam kaitannya dengan isu yang diangkat (Bryman, 2004). Lebih lanjut, metode penelitian kualitatif yang digunakan akan lebih berfokus pada penggunaan data berbentuk narasi dibandingkan numerik. Hal ini berlaku baik dalam proses pengumpulan data maupun analisis data tersebut. Selain itu, metode ini akan memberikan gambaran mendalam yang sistematis dan logis serta memiliki kecenderungan untuk mencakup lebih banyak hal dibandingkan dengan penelitian kuantitatif berbasis statistik (Neuman, 2014).

Metode penelitian kualititatif digunakan untuk memberikan gambaran lebih jelas dan detail dalam menjawab pertanyaan penelitian yang telah diajukan terkait non-traditional security threat penanganan pengungsi dan pencari suaka di Indonesia. Dalam konteks ini, metode penelitian kualititatif digunakan agar penelitian ini mampu menunjukan gambaran yang utuh terkait kebijakan penanganan pengungsi asing di Indonesia yang pada satu sisi justru akan menimbulkan permasalahan baru dan dapat mengancam stabilitas keamanan di Indonesia sendiri. Untuk menjawab permasalahan utama dalam kajian ini, data-data sebagaimana telah ditentukan bersumber dari buku-buku, jurnal arktikel, hingga pada berbagai jenis berita. Pada bagian akhir, analisis akan dilakukan berdasarkan bukti-bukti empiris yang telah ditemukan yang mengarahkan kajian pada isu non-traditional security threats penanganan pengungsi dan pencari suaka di Indonesia.

\section{HASIL DAN PEMBAHASAN}

Kendati Indonesia telah menerbitkan peraturan presiden tentang penanganan pengungsi dan pencari suaka, namun pada kenyataannya masalah-masalah sosial yang berkaitan dengan kehidupan Pengungsi dan Pencari Suaka masih menjadi momok yang dinilai dapat mengganggu stabilitas dan keamanan nasional. Hadirnya isu dan ancaman ini setidaknya dapat diidentifikasi melalui tiga peluang yang memicu timbulnya permasalahan baru antara lain dilematika izin tinggal tanpa batas, masih adanya kesenjangan aturan-aturan di dalam Perpres No. 125 tahun 2016 dengan aturan undang-undang lainnya, serta minimnya alokasi anggaran penanganan pengungsi dan pencari suaka yang berkelanjutan.

\section{Dilematika Izin Tinggal tanpa Batas}

Kendati Indonesia tidak meratifikasi Konvensi Jeneva tahun 1951 dan Protokol tahun 1967, Indonesia mengadopsi prinsip nonrefoulement yang menjadi dasar dalam penerbitan Perpres No. 125 Tahun 2016. Prinsip ini melarang negara untuk mengusir maupun mengembalikan Pengungsi ke negara asalnya yang dapat mengakibatkan hak kebebasan dan kehidupannya terancam. Akibat prinsip non-refoulement tersebut, saat ini Indonesia hanya memiliki dua pilihan alternatif untuk mengembalikan Pengungsi dan Pencari Suaka ke negara asalanya, yaitu melalui deportasi dan pemulangan secara suka rela. Sisanya, Pengungsi dan Pencari Suaka tetap harus menunggu waktu penempatan di negara ketiga kendati saat ini banyak negara yang menjadi anggota dalam konvensi Jeneva 1951 menutup akses kewarganegaraan baru bagi Pengungsi dan Pencari Suaka. Kondisi seperti ini mengakibatkan banyak Pengungsi dan Pencari Suaka harus menetap sementara waktu di Indonesia tanpa 
adanya kepastian dari UNHCR. Bahkan pemberitaan yang dirilis media Kompas.com melansir berita Pengungsi Afghanistan berinisial H (22 thn) dan rekan-rekannya telah berada di Indonesia selama hampir 8 tahun tanpa adanya kepastian kapan kelompok Pengungsi ini mendapatkan status kewarganegaraan baru di negara ketiga hingga pada akhirnya mayoritas dari mereka banyak yang menderita depresi (Kompas.com, 2021).

Kondisi dilematis ini juga disinyalir menstimuli permasalahan-permasalahan sosial lainnya. Adanya larangan bekerja ataupun mencari nafkah bagi Pengungsi maupun Pencari Suaka yang menunggu penempatan di negara ketiga memicu praktik-praktik prostitusi maupun pekerjaanpekerjaan ilegal lainnya. Realitas ini dapat dilihat dari pemberitaan penggerebekan di beberapa apartemen di Jakarta dan tempat hiburan malam di Batam dimana ditemukan pengungsi Afghanistan bekerja sebagai pekerja seks komersial (detiknews, 2017) (jpnn.com, 2016). Selain masalah prostitusi, problematika yang muncul di tengah izin tinggal yang tidak terbatas adalah fenomena pernikahan campur dengan penduduk lokal. Seiring dengan interaksi sosial Pengungsi dengan penduduk lokal yang terjalin bertahuntahun, fenomena kawin campur menjadi salah satu persoalan yang tidak bisa dihindari. Pada umumnya, pengungsi yang dikategorikan ke dalam stateless person memerlukan serangkaian dokumen untuk memenuhi persyaratan menikah dengan penduduk lokal (Sabrina, 2018). Hal ini menjadi situasi yang sulit manakala mayoritas Pengungsi tidak membawa dokumen identitas apapun selama perjalanan migrasi ke Indonesia. Sehingga menikah secara sirih dipilih meskipun opsi ini menjadi risiko bagi penduduk lokal akibat tidak adanya payung hukum yang melindungi hak dari WNI tersebut.

\section{Kesenjangan Aturan Penanganan Pengungsi dalam Perpres No. 125 Tahun 2016}

Permasalahan terkait kesenjangaan aturan penanganan Pengungsi dan Pencari Suaka masih ditemukan di dalam diksursus Perpres No. 125 Tahun 2016. Kesenjangan ini ditemukan Adanya kesenjangan dalam aturan penanganan pengungsi dan pencari suaka dengan aturan-aturan lainnya setidaknya telah menjadi arus utama kajian Novianti (2019) dan Syahrin \& Pangestu (2019). Kedua penelitian tersebut, secara umum, membahas tentang efektivitas dan instrumen pengawasan terhadap implementasi peraturan penanganan Pengungsi dan Pencari suaka yang kini juga menjadi perhatian seluruh lembagalembaga pemerintahan di daerah.

Penelitian Novianti (2019) yang berjudul 'Implementasi Perpres No. 125 tahun 2016 tentang Penanganan Pengungsi dari Luar Negeri' mengangkat permasalahan utama mengenai implementasi kebijakan Perpres No. 125 Tahun 2016 dan keterkaitannya dengan Undang-Undang No. 6 Tahun 2011 tentang Keimigrasian dan Undang-Undang No. 37 Tahun 1999 tentang Hubungan Luar Negeri. Meskipun kebijakankebijakan sebagaimana yang diamanatkan dalam PP No. 125 Tahun 2016 merupakan bagian dari perpanjangan tangan implementasi terhadap UU No. 6 tahun 2011 dan UU No. 37 Tahun 1999, namun pada kenyataannya masih ditemukannya aturan-aturan yang saling bertentangan dimana mekanisme masuknya Pengungsi dan Pencari Suaka tidak sejalan dengan aturan yang telah ditetapkan melalui UU No. 6 Tahun 2011. Sedangkan dalam UU No. 37 tahun 1999 mengenai hubungan luar negeri, aturan-aturan yang bertolakbelakang dengan Perpres No, 125 tahun 2016 ditemukan pada mekanisme pemberian status pencari suaka yang tidak dijelaskan sama sekali, padahal dalam pasal 25 UU Luar Negeri menjelaskan bahwa mekanisme pemberian suaka menjadi wilayah kewenangan presiden dengan mempertimbangkan Menteri.

Selaras dengan penelitian Novianti (2009), kajian yang dipublikasikan Syahrin \& Pangestu (2019) menitikberatkan skema pengawasan terhadap Pengungsi dan Pencari Suaka pasca implementasi PP No. 125 Tahun 2016. Mengacu pada kebijakan pemerintah sebagaimana tertuang dalam UU No. 6 Tahun 2011 dan PP No. 125 Tahun 2016, Rumah Detensi Imigrasi (Rudenim) merupakan salah satu instrumen utama pemerintah dalam melaksanakan pengawasan terhadap orang asing khususnya mobilitas Pengungsi dan Pencari Suaka di Indonesia. Namun, meskipun pelaksanaan pengawasan terhadap Pengungsi dan Pencari Suaka sebagaimana amanat yang dijalankan oleh Rudenim telah berjalan optimal, namun kebijakan pemerintah yang tertuang melalui PP No. 125 tahun 2016 perlu disempurnakan dengan aturanaturan teknis yang dapat menjamin seluruh instrumen hukum terkait pengawasan Pengungsi dan Pencari Suaka berjalan maksimal seperti penetapan standar operasional prosedur (SOP) mekanisme pengawasan bagi seluruh satuan kerja rumah detensi imigrasi, alokasi biaya dan operasional pengawasan, penetapan pejabat pelaksana teknis yang dapat melaksanakan pengawasan dan penjatuhan sanksi akibat kelalaian terkait manajemen risiko pengawasan Pengungsi dan Pencari Suaka. 
Merujuk dari hasil analisis dua kajian di atas, setidaknya dapat dipahami bahwa implementasi Perpres No. 125 Tahun 2016 belum memenuhi ekspektasi pengawasan dan prosedur manajemen Pengungsi dan Pencari Suaka yang optimal. Kondisi ini dinilai menjadi salah satu celah maupun peluang kejahatan-kejahatan perdagangan manusia untuk mengarahkan kelompok-kelompok pengungsi menuju wilayah Indonesia. Selain itu, keterlibatan banyak sub aktor negara dan non negara dalam manajemen Pengungsi dan Pencari Suaka hanya memberikan pekerjaan rumah baru dalam isu-isu kemanusian di tengah permasalahan sosial yang terjadi saat ini. Kenyataan ini makin diperparah seiring kondisi pandemi Covid-19 yang terjadi di berbagai wilayah di Indonesia dimana kepentingan nasional menjadi fokus utama pemerintah sejak terjadinya penyebaran pandemi di awal tahun 2019 .

\section{Minimnya Alokasi Anggaran Penanganan Pengungsi dan Pencari Suaka yang Berkelanjutan}

Realitas ini menjadi salah satu ancaman yang muncul di tengah diskursus persoalan Pengungsi dan Pencari Suaka di Indonesia. Pengungsi yang terdaftar di UNHCR pada umumnya memiliki income bulanan sebesar Rp. 1.250.000,- per kepala. Alokasi ini dinilai masih belum memenuhi standar hidup layak di kota-kota besar di Indonesia. Selain memperoleh bantuan dari organisasi IOM dan UNHCR, pengungsi yang menjalani masa transit di Indonesia juga mendapatkan bantuan sukarela dari NGO maupun penduduk setempat. Kondisi minimnya bantuan sosial yang diperoleh pengungsi juga diperparah dengan rencana penghentian bantuan finansial oleh UNHCR maupun IOM mengingat donasi dana yang diperoleh dari donatur semakin menipis dan tidak mencukup untuk menutup biaya operasional di Indonesia.

Pemerintah pusat dan daerah sebagai aktor negara tidak memiliki anggaran yang signifikan dalam menyalurkan bantuan finansial bagi Pengungsi dan Pencari Suaka. Keterbatasan belanja negara juga terjadi di satuan kerja pelaksa teknis Rumah Detensi Imigrasi yang memiliki wewenang dalam pengawasan mobilitas Pengungsi dan Pencari Suaka di wilayah-wilayah penampungan seperti Jakarta, Bogor, Medan, Batam, Surabaya dan Makassar. Masalah ini tidak hanya menstimuli Pengungsi untuk berusaha memperoleh income tambahan secara ilegal, tetapi juga terbatasnya anggaran bagi satuan kerja pelaksana yang membidangi pengawasan akan menciptakan fungsi monitor dan pengawasan yang kurang optimal.

\section{KESIMPULAN}

Realitas isu Pengungsi dan Pencari Suaka di Indonesia dianalogikan seperti bom waktu yang dapat mengganggu stabilitas dan keamanan nasional. Empat tahun pasca implementasi Perpres No. 125 Tahun 2016, isu ini dinilai tidak dapat diatasi secara signifikan. Kenyataan ini mengacu pada masih adanya kesenjangan aturan dengan peraturan perundang-undangan lainnya yang memiliki kesetaraan kewenangan dalam melaksanakan manajemen Pengungsi dan Pencari Suaka. Selain itu, prinsip non-refoulement yang dianut pemerintah dan absennya regulasi terkait masa izin tinggal di Indonesia, dapat memicu peluang bertambahnya populasi baru pengungsi dan pencari suaka. Hal ini juga diperparah dengan rangkaian kebijakan hard policy imigrasi Australia yang cenderung bersikap keras dan sentimen terhadap kedatangan Pengungsi dan Pencari Suaka yang diselundupkan melalui pelabuhan-pelabuhan kecil di wilayah pesisir selatan di Indonesia.

Kenyataan ini merupakan satu contoh nyata dimana pada dasarnya negara harus bersikap serius terhadap kepentingan dan keamanan nasional. Langkah startegis yang dapat dilakukan dalam merespon permasalahan ini salah satunya adalah meningkatkan fungsi pengawasan yang tidak hanya terbatas pada pergerakan migrasi pengungsi dan pencari suaka di wilayah Indonesia tetapi juga pengawasan terhadap kepentingankepentingan aktor non-negara yang turut andil dalam keberlangsungan hidup pengungsi dan pencari suaka di Indonesia.

\section{REFERENSI}

Bryman, A. (2004). Social Research Methods. New York: Oxford University Press.

Buzzan, Barry, Ole Waever, and Wilde Jaap de. (1998). Security: A New Framework for Analysis. Colorado: Lynne Rienner Publisher, Inc.

Caballero-Anthony, M. (2016). "An Introduction to Non-Traditional Security Studies." In Understanding Non-Traditional Security, by Caballero-Anthony, 3-19. London: Sage Publications.

Chaijaroenwatana, Bussabong, and Md Mahbubul Haque. (2020). "Displaced Rohingya and Concern for Non-Traditional Security Risk in Thailand." Asian Affairs: An American Review Vol. 47 Issue 3 1-25. 
detiknews.com. (2017). Imigrasi Tangkap 2 PSK Pria Asal Afganistan di Kalibata City. April 27. Accessed June 19, 2021. https://news.detik.com/berita/d3485380/imigrasi-tangkap-2-psk-pria-asalafganistan-di-kalibata-city.

Dillon, Paul. (2006). Penanganan Pengungsi Internal. IDP Management Fact Sheet, Jakarta: IOM Indonesia.

Fandik, Mohammad. (2013). "Penampungan Orang Vietnam di Pulang Galang 19751979." AVATARA Vol. 1 No. 1 164-172.

jpnn.com. (2016). Walah Pengungsi Afganistan Menyambi jadi Gigolo di Batam. September 8. Accessed June 19, 2021. https://www.jpnn.com/news/walahpengungsi-afghanistan-menyambi-jadigigolo-di-batam.

Kompas.com. (2021). Kisah Pengungsi Afganistan, Bertahun-tahun Terkatungkatung hingga Depresi. May 7. Accessed June 19, 2021. https://regional.kompas.com/read/2021/05/07 /200511778/kisah-pengungsi-afganistanbertahun-tahun-terkatung-katung-hinggadepresi?page $=$ all.

Lumentut, Dhea T, Yan G. Pelamonia, and Johni R.V Korwa. (2020). "Analisis Kebijakan Luar Negeri John Howard terhadap Imigran Ilegal di Australia." Jurnal Asia Pacific Studies Vol 4 No. 1 46-59.

Maing, Skolastika G, and M. Elfan Kukab. (2020). "Dilema Politik Luar Negeri Australia dalam Penanganan Pengungsi dan Pencari Suaka." Jurnal Penelitian dan Pengabdian Kepada Masyarakat UNSIQ Vol. 8 No. 1 28-39.

McAuliffe, Marie. (2016). Resolving Policy Conundrums: Enhancing Humanitarian Protection in Southeast Asia. Washington DC: Migration Policy Institute.

Mlynarska, Katarzyna Marzeda. (2016). "NonTraditional Security Challenges and Regional Governance: Eu and ASEAN Answer to Migration Crisis." CEEISA-ISA Conference. Ljubljana: University of Ljubljana. 1-21.

Myint, Thuzar. (2012). "Non-Traditional Security Issues at Myanmar-India Border (19882008)." Dagon University Research Journal Vol. 4 77-83.
Neuman, L. (2014). Sosical Research Methods: Qualitative and Quantitative Approaches. London: Pearson.

Novianti. (2019). "Implementasi Perpres No. 125 Tahun 2016 tentang Pengananan Pengungsi dari Luar Negeri." Negara Hukum Vol. 10 No.2 281-300.

Nugroho, FX Julian Dwi. (2020). Efektivitas Perpres No. 125 Tahun 2016 tentang Penanganan Pengungsi dari Luar Negeri dalam Mengatasi Permasalahan Pengungsi dari Negara Lain sebelum Menuju Negara Ketiga. Undergraduate Thesis, Sleman: Universitas Atmajaya Yogyakarta.

Prahenti, Dindya Sisca. (2013). "Dampak Singgahnya Pencari Suaka ke Australia terhadap Peningkatan Kejahatan Transnasional di Indonesia." Jurnal Analis Hubungan Internasional Vol.2 No.2 83-122.

Pugh, Michael. (2004). "Drowning not Waving: Boat People and Humanitarianism at Sea." Journal of Refugee Studies Vol. 27 (4): 5069.

Sabrina, Alfiah. (2018). "Perlindungan Hukum terhadap WNI yang Menikah dengan Pengungsi yang Berstatus Stateless Person." Justisia Jurnal Hukum Vol. 2 No. 2 207-223.

Stange, Gunnar, Patrick Sakdapolrak, Kwanchit Sasiwongsaroj, and Matthias Kourek. (2019). "Forced Migration in Southeast Asia: A Brief Overview of Current Research." Austrian Journal of South-East Asian Studies 12 (2): 249-265.

Sudiar, Sonny. (2019). "Pendekatan Keamanan Manusia dalam Studi Perbatasan Negara." Jurnal Hubungan Internasional Vol. 7 No. 2 152-160\.

Syahrin, M. Alvi, and Bangun Widodo Pangestu. (2019). "Diskursus Skema Pengawasan Pengungsi Setelah Penerbitan Peraturan Presiden No. 125 Tahun 2016 tentang Penanganan Pengungsi dari Luar Negeri dalam Perspektif Keimigrasian." Jurnal Ilmiah Kajian Keimigrasian Vol. 2 No. 171 84.

The Jakarta Post. (2015). RI Seeking Solution to Illegal Migration. Jakarta, November 28.

UNHCR Indonesia. (2021). Laporan Statistik Bulanan Maret 2021. Monthly Report, Jakarta: UNCHR Indonesia. 
UNHCR. (2021). The Displaced and Stateless of Myanmar in the Asia-Pacific Region. Annual Report, Bangkok: UNHCR.

US Committee for Refugees and Immigrants. (2001). USCR Country Report Indonesia: Statistics on Refugees and other Uprooted People, June 2001. Jun 19. Accessed 6 15, 2021.

https://reliefweb.int/report/indonesia/uscrcountry-report-indonesia-statistics-refugeesand-other-uprooted-people-jun.

Yulianto, Rohmad Adi. (2020). "Integrasi Prinsip Non-Refoulement dengan Prinsip Jus Cogens pada Kebijakan Penanganan Pengungsi di Indonesia." Jurnal Ilmiah Kebijakan Hukum Vol. 14 No. 3 493-516.

\section{PROFIL PENULIS}

Penulis merupakan mahasiswa Pascasarjana Ilmu Hubungan Internasional, FISIP, Universitas Indonesia. 